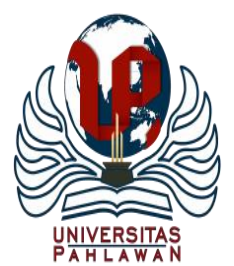

\title{
JURNALBASICEDU
}

Volume 5 Nomor 5Tahun 2021 Halaman 3186 - 3195

Research \&Learningin Elementary Education https://jbasic.org/index.php/basicedu

\section{Analisis Penilaian Keterampilan Kurikulum 2013 pada Pembelajaran Daring Kelas Tinggi Sekolah Dasar}

\author{
Hani Subakti $^{1 凶}$, Gamar Al Haddar ${ }^{2}$, Elizabeth Angela Orin ${ }^{3}$
}

Pendidikan Guru Sekolah Dasar, Universitas Widya Gama Mahakam Samarinda, Indonesia ${ }^{1,2,3}$,

E-mail: hanisubakti@uwgm.ac.id ${ }^{1}$,gamar@uwgm.ac.id ${ }^{2}$, elizabethangelaorinerdit@gmail.com $^{3}$

\begin{abstract}
Abstrak
Penelitian ini dilaksanakan di SD Negeri 002 Samarinda Utara, Kelurahan Lempake, Kecamatan Samarinda Utara, Kota Samarinda, Provinsi Kalimantan Timur. Tujuan penelitian ini adalah mengetahui cara penilaian keterampilan dalam pembelajaran daring pada siswa kelas IVB di SDNegeri 002 Samarinda Utara. Subjek dalam penelitian ini adalah guru, kepala sekolah, dan siswa. Metode pengumpulan data yaitu wawancara dan dokumentasi. Uji keabsahan data melalui triangulasi sumber. Jenis Penelitian ini termasuk dalam penelitian kualitatif.Hasil penelitian menunjukan bahwa (1) teknik penilaian yaitu keterampilan praktik dalam pembelajaran daring ini telah dilaksanakan oleh guru dan siswa diberikan tugas praktik menyanyi berupa video yang dikirim melalui aplikasi whatsapp pribadi guru menggunakan media gawai. (2) Penilaian keterampilan produk sudah dilaksanakan oleh guru dengan cara memberikan siswa tugas membuat kolase dan bukti hasil karya difoto bersama siswa. (3) Penilaian keterampilan proyek dan portofolio tidak dilaksanakan karena dalam pembelajaran daring sulit untuk melakukan dua teknik penilaian ini. (4) Dalam menjalankan penilaian keterampilan saat pembelajaran daring, jika terdapat kendala pada siswa,di mana siswa belum memahami tujuan dari muatan materi yang disampaikan, maka guru akan memberikan penjelasan ulang dan meminta orang tua siswa untuk membimbing anaknya di rumah.
\end{abstract}

Kata Kunci: Penilaian keterampilan, pembelajaran daring.

\begin{abstract}
This research was conducted at SD Negeri 002 North Samarinda, Lempake Village, North Samarinda District, Samarinda City, East Kalimantan Province. The purpose of this study was to determine how to assess skills in online learning for class IVB students at SD Negeri 002 North Samarinda. The subjects in this study were teachers, principals, and students. Data collection methods are interviews and documentation. Test the validity of the data through triangulation of sources. This type of research is included in qualitative research. The results showed that (1) the assessment technique, namely practical skills in online learning, had been carried out by the teacher and students were given singing practice assignments in the form of videos sent via the teacher's personal WhatsApp application using mobile media. (2) The product skill assessment has been carried out by the teacher by giving students the task of making collages and proof of their work being photographed with the students. (3) Assessment of project and portfolio skills is not carried out because in online learning it is difficult to carry out these two assessment techniques. (4) In carrying out a skills assessment during online learning, if there are obstacles to students, where students do not understand the purpose of the content of the material presented, the teacher will give a re-explanation and ask the parents of students to guide their children at home.
\end{abstract}

Keywords: Skills assessment, online learning

Copyright (c) 2021 Hani Subakti, Gamar Al Haddar, Elizabeth Angela Orin

$\triangle$ Corresponding author :

Email: hanisubakti@uwgm.ac.id

DOI : https://doi.org/10.31004/basicedu.v5i5.1300

ISSN 2580-3735 (Media Cetak)

ISSN 2580-1147 (Media Online) 
3187 Analisis Penilaian Keterampilan Kurikulum 2013 pada Pembelajaran Daring Kelas Tinggi Sekolah Dasar - Hani Subakti, Gamar Al Haddar, Elizabeth Angela Orin

DOI: https://doi.org/10.31004/basicedu.v5i5.1300

\section{PENDAHULUAN}

Dalam Undang-undang No. 20 tahun 2003 Pasal 1 dikatakan "Pendidikan adalah usaha secara sadar dan terencana untuk mewujudkan suasana belajar dan proses pembelajaran agar peserta didik secara aktif mengembangkan potensi dirinya di mana guru berperan penting dalam proses belajar siswa. Chomaidi dan Salamah (2018) pendidikan nasional adalah pendidikan yang berdasarkan Pancasila dan Undang-Undang Dasar Negara Republik Indonesia Tahun 1945 yang berakar pada nilai-nilai agama, kebudayaan nasional Indonesia dan tanggap terhadap tuntutan perubahan zaman. Sistem Pendidikan adalah keseluruhan komponen pendidikan yang saling terkait secara terpadu untuk mencapai tujuan pendidikan nasional.

Guru merupakan seorang tenaga pendidik profesional yang mendidik, mengajarkan suatu ilmu, membimbing, melatih, memberikan penilaian, serta melakukan evaluasi kepada siswa (Subakti, 2019). Guru juga bertanggung jawab atas ilmu pengetahuan yang diajarkannya kepada siswa karena guru merupakan fasilitator dan motivator dalam memberikan materi pembelajaran. Guru harus mampu membuat penilaian berdasarkan tujuan pembelajarannya, guru dapat mengembangkan bahan ajar baik dari buku, media, instrumen penilaian pembelajaran dan model-model kegiatan pembelajaran dan melakukan eksperimen penilaian untuk melihat keefektifan metode atau media yang digunakan (Agustina, 2018).

Penilaian keterampilan merupakan penilaian yang dilakukan untuk mengukur kemampuan siswa dalam mencapai kompetensi inti keterampilan dan penilaian keterampilan juga dilakukan untuk mengetahui kemampuan siswa dalam menerapkan pengetahuannya untuk melakukan tugas atau kegiatan (Sarkadi, 2020). Kompetensi inti keterampilan merupakan salah satu komponen kompetensi inti yang terdapat dalam kurukulum 2013. Kurikulum 2013 sendiri terdapat berberapa kompetensi inti di antaranya adalah KI-1 yang mengukur penilaian sikap spiritual, KI-2 mengukur sikap sosial, KI-3 mengukur pengetahuan dan KI-4 mengukur keterampilan. Penilaian keterampilan dimaksudkan untuk mengetahui apakah pengetahuan yang sudah dikuasai siswa dapat digunakan untuk mengenal dan menyelesaikan masalah dalam kehidupan sesungguhnya (Musfiqon, 2016). Seiring perkembangan zaman banyak hal yang dapat dilakukan untuk menilai keterampilan seorang siswa saat mengembangkan ilmu pengatahuannya dalam mengikuti kegiatan pembelajaran tergantung muatan dan tujuan pelajaran.

Pembelajaran dikembangkan melalui konsep belajar, penekanannya terletak pada perpaduan antara keduanya yakni kepada penumbuhan aktivitas siswa dan konsep tersebut dipandang sebagai sistem yang terdiri dari berbagai komponen (Subakti, 2020). Pembelajaran daring sangat dikenal dikalangan masyarakat dan akademik dengan istilah pembelajaran dalam jaringan atau istilah yang sangat umum diketahui adalah pembelajaran jarak jauh, pembelajaran daring merupakan pembelajaran yang berlangsung di dalam jaringan di mana pengajar dan yang diajar tidak bertatap muka secara langsung. Pembelajaran daring di masa seperti sekarang ini sangat berperan penting dalam proses pendidikan dan kemajuan siswa dalam mendapatkan ilmu. Pembelajaran daring juga memiliki kelebihan dan kekurangannya tetapi masih dapat diatasi dengan berbagai macam cara dan solusi yang menunjang.

Berdasarkan hasil observasi yang dilakukan saat penerapan pembelajaran daring di SD Negeri 002 Samarinda Utara peneliti menemukan berberapa masalah dan kendala yang dialami guru maupun siswa kelas IVB. Masalah yang ditemukannya itu di mana saat pembelajaran daring menuntut guru dan siswa harus terbiasa beradaptasi dengan keadaan pembelajaran yang telah diterapkan. Masalah dan kendala yang biasanya dialami adalah saat melakukan penilaian hasil belajar serta penilaian pemahaman siswa terhadap materi dan tugas yang telah diberikan oleh guru kelas. Untuk mengatasi masalah penilaian guru kelas IVB menggunakan penilaian keterampilan untuk mengukur pemahaman dan kreativitas siswanya pada saat pembelajaran daring seperti ini. 
3188 Analisis Penilaian Keterampilan Kurikulum 2013 pada Pembelajaran Daring Kelas Tinggi Sekolah Dasar - Hani Subakti, Gamar Al Haddar, Elizabeth Angela Orin

DOI: https://doi.org/10.31004/basicedu.v5i5.1300

\section{METODE PENELITIAN}

Penelitian ini menggunakan metode penelitian deskriptif kualitatif. Tempat penelitian ini dilaksanakan di SD Negeri 002 Samarinda Utara, Jalan Poros Gang Andhika, Kelurahan Lempake, Kecamatan Samarinda Utara, Kota Samarinda, Provinsi Kalimantan Timur. Waktu pelaksanaan penelitian ini dilaksanakan pada bulan Maret s.d. April 2021 di SD Negeri 002 Samarinda Utara. Populasi pada penelitian ini yaitu SD Negeri 002 Samarinda Utara dan subjek dalam penelitian ini adalah Kepala SD Negeri 002, Guru kelas IVB, dan siswa kelas IVB.

Teknik pengumpulan data dalam penelitian ini peneliti menggunakan wawancara semi terstruktur dan dokumentasi. Peneliti juga melakukan taknik analisis data dalam 3 tahap yaitu: (1) Reduksi data yaitu memilih hal-hal apa saja yang akan diteliti, (2) Penyajian data yaitu dilakukan dalam bentuk tabel, grafik, phie chard, pictogram,dan sejenisnya, (3) Penarikan Kesimpulan adalah langkah dalam melakukan pendeskripsian kesimpulan hasil penelitian. Dalam melakukan pengecekan keabsahan data peneliti melakukan dengan triangulasi sumber. Teknik ini didukung oleh sumber data referensi, rekaman saat wawancara, serta video atau gambar saat melaksanakan wawancara.

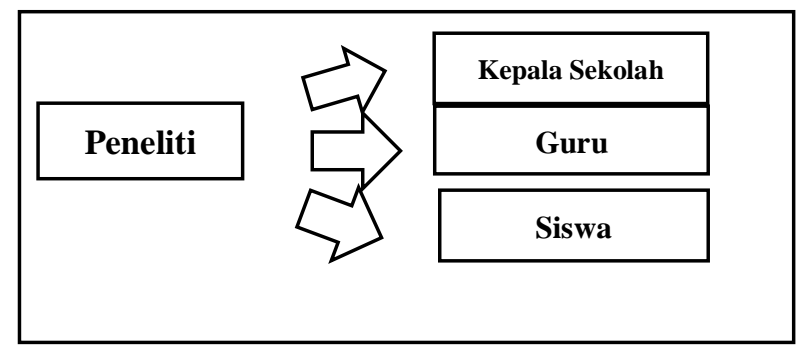

Gambar 1. Teknik Pengumpulan Data (Gora, 2019)

\section{HASIL DAN PEMBAHASAN}

Berdasarkan hasil telaah yang telah dilakukan peneliti bahwa dalam penilaian keterampilan ada berberapa teknik cara penilaian keterampilan yang digunakan guru dalam pembelajaran daring pada siswa kelas IVB antara lain yaitu:

Cara penilaian keterampilan dalam pembelajaran daring seperti sekarang ini guru kelas IVB untuk melakukan penilaian hasil belajar siswa dan untuk mengetahui sampai mana pemahaman yang siswa peroleh, Ibu SH menggunakan teknik penilaian yang sesuai dengan cara penilaian keterampilan dalam kurikulum 2013. Teknik penilaian keterampilan ada empat teknik yaitu teknik penilaian praktik, produk, proyek, dan portofolio. Akan tetapi Ibu SH hanya menggunakan teknik penilaian keterampilan praktik dan produk saja karena menimbang teknik ini mudah untuk disampaikan dan dipahami oleh siswa saat pembelajaran daring seperti ini. Saat pembelajaran daring seperti ini Ibu SH menyampaikan materi keterampilan ataupun tugas melalui paguyuban kelas yang menggunakan sarana media gawai, untuk materi ataupun panduan pengerjaan tugas sudah terdapat di dalam LKS yang telah dimiliki oleh siswa. Setiap masalah atau kendala yang dihadapi siswa akan diatasi bersama antara Ibu SH dan orang tua siswa untuk mencari solusi agar siswa dapat mengikuti atau memahami materi pelajaran yang disampaikan saat pembelajaran daring seperti ini.

Tabel 1. Hasil Penelitian

\begin{tabular}{cllrlrlr}
\hline No & Indikator & \multicolumn{2}{c}{ Kepala Sekolah } & \multicolumn{2}{c}{ Guru } & \multicolumn{2}{c}{ Siswa } \\
\hline 1. & Instrumen & Penilaian atau & Penggunaan & instrumen & Dalam & penggunaan \\
& penilaian & pencapaian hasil belajar & penilaian keterampilan & instrumen & penilaian \\
& keterampilan & keterampilan sekolah & menggunakan keempat & keterampilan & Ibu SH \\
& & menggunakan instrumen & komponen penilaian yang & menggunakan & LKS \\
& & penilaian keterampilan & ada dalam penilaian & dalam melakukan atau \\
& & siswa yang berupa & keterampilan & pada & memberikan & tugas \\
& & lembar kerja siswa dari & kurikulum 2013 dan setiap & kepada siswa dimana \\
\hline
\end{tabular}




\begin{tabular}{|c|c|c|c|c|}
\hline & & $\begin{array}{l}\text { buku guru dan untuk } \\
\text { lembar kerja siswa } \\
\text { lainnya tergantung } \\
\text { kepada setiap guru } \\
\text { bagaimana membuat } \\
\text { lembar kerja siswa } \\
\text { sekreatifnya sehingga } \\
\text { dapat digunakan dalam } \\
\text { penilaian keterampilan } \\
\text { pada siswa. }\end{array}$ & $\begin{array}{l}\text { instrumen penilaian yang } \\
\text { dilakukan mengikuti } \\
\text { sesuai dengan yang ada } \\
\text { dalam kompetensi dasar } \\
\text { atau target pencapaian } \\
\text { hasil belajar yang ada di } \\
\text { dalam buku yang } \\
\text { digunakan. }\end{array}$ & $\begin{array}{l}\text { LKS tersebut didapatkan } \\
\text { dengan cara para siswa } \\
\text { membeli sendiri sehingga } \\
\text { mempermudah dalam } \\
\text { mengerjakan tugas yang } \\
\text { diberikan karena di } \\
\text { dalam LKS tersebut } \\
\text { sudah ada cara dan } \\
\text { penjelasan tugas yang } \\
\text { akan dikerjakan. }\end{array}$ \\
\hline 2. & $\begin{array}{l}\text { Teknik } \\
\text { Penilaian } \\
\text { Keterampilan }\end{array}$ & $\begin{array}{l}\text { Penilaian keterampilan } \\
\text { menggunakan teknik } \\
\text { atau cara khusus untuk } \\
\text { melakukan penilaian } \\
\text { yang sesuai dengan } \\
\text { standar penilaian yang } \\
\text { ada di dalam kurikulum } \\
2013 \text { dan yang sesuai } \\
\text { dengan kemampuan } \\
\text { guru serta siswa dan } \\
\text { para siswa juga pernah } \\
\text { diberikan produk yaitu } \\
\text { membuat produk } \\
\text { membuat } \\
\text { dinding. }\end{array}$ & $\begin{array}{l}\text { Dalam melakukan } \\
\text { penilaian keterampilan } \\
\text { menggunakan berberapa } \\
\text { teknik penilaian dengan } \\
\text { standar penilaian } \\
\text { kurikulum } 2013 \text { yang di } \\
\text { mana dalam penilaian } \\
\text { keterampilan ini terdiri } \\
\text { dari empat teknik } \\
\text { penilaian keterampilan } \\
\text { yaitu penilaian praktik, } \\
\text { proyek, produk, dan } \\
\text { portofolio. } \\
\text { penilaian keterampilan Ibu } \\
\text { SH hanya menggunakan } \\
\text { teknik penilaian praktik } \\
\text { dan produk saja serta } \\
\text { dalam penilaian praktik } \\
\text { para siswa diberikan tugas } \\
\text { praktik menyanyi dan } \\
\text { menari serta dalam } \\
\text { penilaian produk siswa } \\
\text { diberikan tugas membuat } \\
\text { karya seperti membuat } \\
\text { montase dan kolase yang } \\
\text { dijelaskan terlebih dahulu } \\
\text { melalui paguyuban kelas } \\
\text { dan biasanya siswa } \\
\text { menggunakan LKS di } \\
\text { mana dalam LKS tersebut } \\
\text { sudah terdapat cara dan } \\
\text { petunjuk dalam } \\
\text { mengerjakan tugas yang } \\
\text { diberikan oleh guru. }\end{array}$ & $\begin{array}{l}\text { Dalam memberikan tugas } \\
\text { keterampilan Ibu SH } \\
\text { memberikan tugas } \\
\text { praktik menyanyi, tugas } \\
\text { produk yang berupa } \\
\text { membuat montase dan } \\
\text { kolase, serta tugas proyek } \\
\text { melihat pertumbuhan } \\
\text { bunga dan untuk } \\
\text { pengumpulan hasil karya } \\
\text { hanya berupa foto atau } \\
\text { video yang dikirim } \\
\text { melalui whatsapp sebagai } \\
\text { bukti bahwa siswa telah } \\
\text { mengerjakan tugas yang } \\
\text { diberikan. }\end{array}$ \\
\hline 3. & $\begin{array}{l}\text { Hasil } \\
\text { penilaian } \\
\text { keterampilan }\end{array}$ & $\begin{array}{l}\text { Cara menilai hasil } \\
\text { keterampilan tergantung } \\
\text { cara dan teknik yang } \\
\text { dilakukan oleh guru } \\
\text { tetapi tetap berpacu pada } \\
\text { standar hasil yang ada di } \\
\text { dalam kurikulum 2013, } \\
\text { dan jika didapati cara } \\
\text { penilaian keterampilan }\end{array}$ & $\begin{array}{lr}\text { Dalam menilai hasil } \\
\text { belajar keterampilan siswa } \\
\text { Ibu SH melakukan } \\
\text { penilaian hasil dengan cara } \\
\text { menilai dari kualitas dan } \\
\text { kuantitas hasil karya } \\
\text { keterampilandi } & \text { mana } \\
\text { diberi nilai dengan } \\
\text { menggunakan }\end{array}$ & $\begin{array}{l}\text { Dalam merespons hasil } \\
\text { belajar keterampilan } \\
\text { siswa Ibu SH } \\
\text { memberikan respons } \\
\text { terhadap hasil karya } \\
\text { keterampilan yang telah } \\
\text { dikerjakan oleh siswa. }\end{array}$ \\
\hline
\end{tabular}




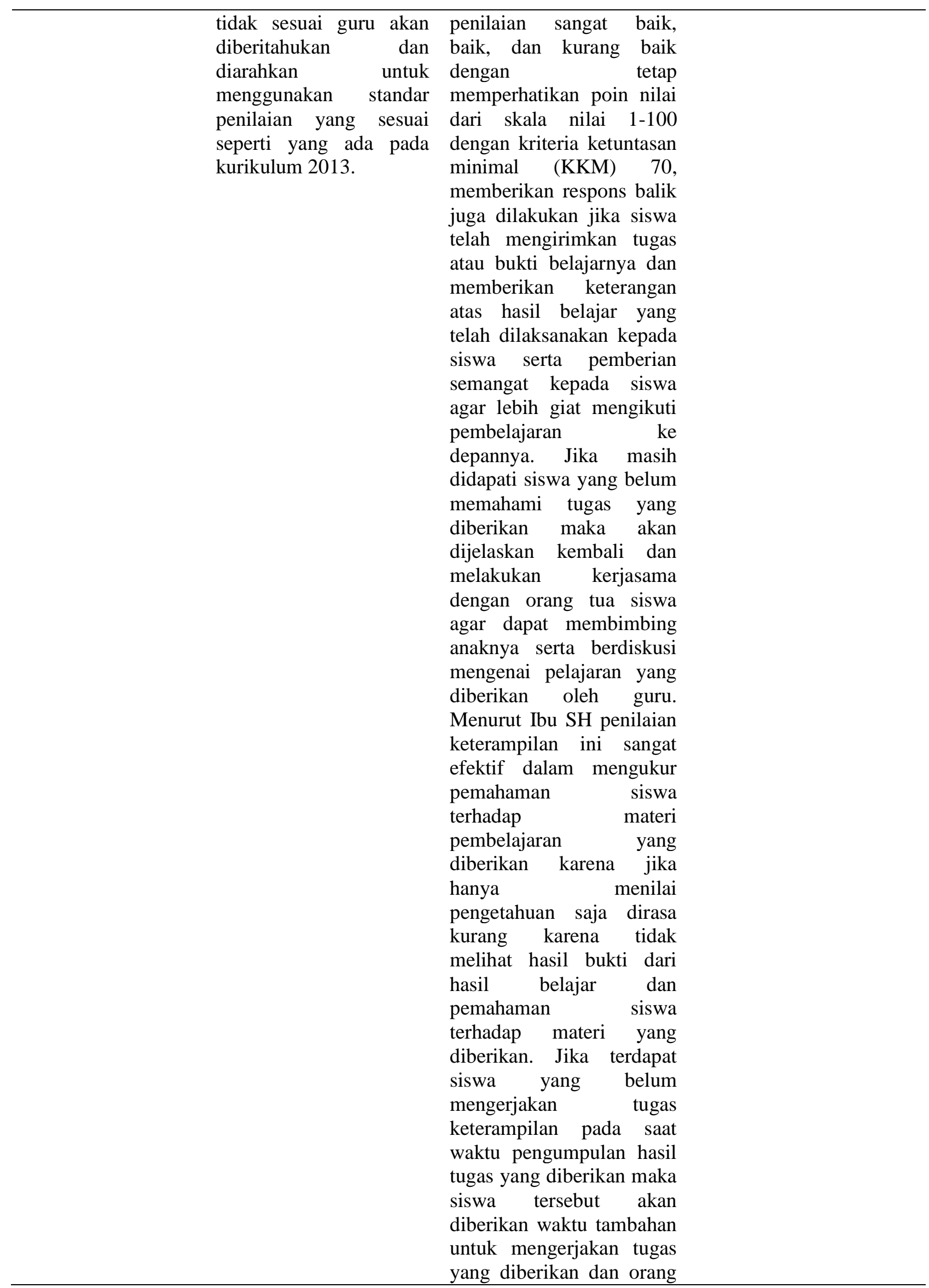




\begin{tabular}{|c|c|c|c|c|}
\hline & & & $\begin{array}{l}\text { tua siswa diminta untuk } \\
\text { membimbing anaknya } \\
\text { dalam pengerjaan tugas di } \\
\text { rumah. Dari hasil yang } \\
\text { didapatkan } \\
\text { pengumpulan tugas jika } \\
\text { ada siswa yang belum } \\
\text { memahami atau mengerti } \\
\text { maksud dari tujuan materi } \\
\text { tugas yang diberikan maka } \\
\text { Ibu SH akan menjelaskan } \\
\text { kembali dan siswa } \\
\text { diberikan kesempatan } \\
\text { untuk bertanya mengenai } \\
\text { materi tugas yang belum } \\
\text { dipahaminya serta akan } \\
\text { diberikan penjelasan ulang } \\
\text { agar siswar dapat } \\
\text { memahami materi yang } \\
\text { disampaikan dalam tugas. }\end{array}$ & \\
\hline 4. & $\begin{array}{l}\text { Pembelajaran } \\
\text { Daring }\end{array}$ & $\begin{array}{l}\text { Saat pembelajaran } \\
\text { daring seperti ini sangat } \\
\text { merepotkan bagi sekolah } \\
\text { karena untuk } \\
\text { penyesuaian belajar } \\
\text { daring ini sangat susah } \\
\text { bagi guru maupun siswa, } \\
\text { terutama bagi siswa } \\
\text { kelas rendah yang belum } \\
\text { paham membaca dan } \\
\text { menulis sehingga untuk } \\
\text { melakukan bimbingan } \\
\text { guru sangat susah. } \\
\text { Penyesuaian rara } \\
\text { mengajar dan belajar } \\
\text { menjadi sangat tidak } \\
\text { efektif. } \quad \text { Banyaknya } \\
\text { kendala yang dialami } \\
\text { saat melaksanakan } \\
\text { pembelajaran daring } \\
\text { seperti ini dan saat } \\
\text { pembelajaran daring } \\
\text { seperti ini kebanyakan } \\
\text { yang mengerjakan tugas } \\
\text { sekolah adalah orang tua } \\
\text { bukan siswanya. }\end{array}$ & 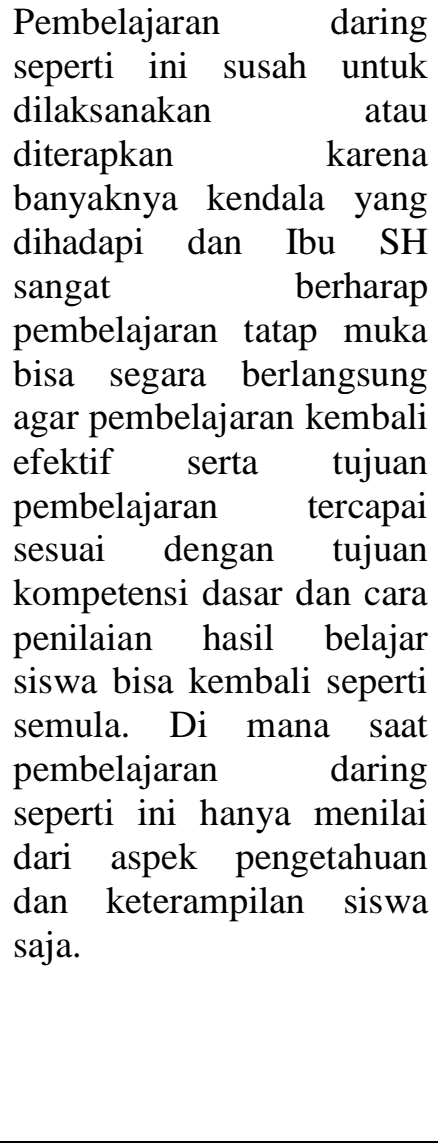 & $\begin{array}{l}\text { Pembelajaran } \\
\text { seperti ini terasa bosan, } \\
\text { melelahkan } \\
\text { tugasnya banyak dan saat } \\
\text { kegiatan belajar hanya } \\
\text { diberikan materi saja, } \\
\text { kegiatannya } \\
\text { kurang. }\end{array}$ \\
\hline$J$ & $\begin{array}{l}\text { Gambaran } \\
\text { umum } \\
\text { pembelajaran } \\
\text { daring }\end{array}$ & $\begin{array}{l}\text { Selain sekolah merasa } \\
\text { kerepotan dari } \\
\text { diterapkannya } \\
\text { pembelajaran daring ini } \\
\text { adapula hambatan- } \\
\text { hambatan yang dihadapi } \\
\text { yaitu di mana terkendala }\end{array}$ & $\begin{array}{l}\text { Pembelajaran daring ini } \\
\text { pembelajaran dilakukan } \\
\text { secara jarak jauh sehingga } \\
\text { untuk penyampaian materi } \\
\text { hanya berupa ceramah } \\
\text { yang dilakukan melalui } \\
\text { video lalu dikirim melalui }\end{array}$ & $\begin{array}{l}\text { Pembelajaran } \\
\text { daringseperti saat ini } \\
\text { hanya mengerjakan tugas } \\
\text { dan mendapatkan } \\
\text { penjelasan } \\
\text { diberikan oleh guru. } \\
\text { Tugas tersebut dikerjakan }\end{array}$ \\
\hline
\end{tabular}




masalah jaringan internet
yang tidak stabil sampai
terkendala dimasalah
tidak semua siswa
memliki gawai sehingga
menjadi sulit mengikuti
pembelajaran daring.
Kita ketahui bersama
bahwa gawai adalah alat
yang umum dan paling
sering digunakan dalam
pembelajaran daring saat
ini. Penilaian hasil
belajar saat pembelajaran
daring ini dinilai dari
aspek pengetahuan dan
keterampilan saja serta
pembelajaran juga tidak
mendapatkanpengawasa
n langsung oleh guru.

\begin{tabular}{ll}
\hline 6. & Media \\
& pembelajaran \\
& daring
\end{tabular}

\begin{tabular}{|c|c|}
\hline $\begin{array}{l}\text { paguyuban kelas dan } \\
\text { untuk setiap respons atau } \\
\text { pengumpulan tugas oleh }\end{array}$ & $\begin{array}{l}\text { dengan cara mencari } \\
\text { dibuku atau diinternet. } \\
\text { Lalu mengumpulkannya }\end{array}$ \\
\hline $\begin{array}{ll}\text { iswa dikirim mela } & \text { Datsp. } \\
\text { vhatsapp. }\end{array}$ & $\begin{array}{l}\text { melalui gawai } \\
\text { guru kelas. }\end{array}$ \\
\hline
\end{tabular}

pembelajaran daring ini juga adapula hambatan dan kendala yang dihadapi yaitu sulitnya menjelaskan materi pelajaran, siswa juga menjadi sulit memahami materi yang disampaikan dan untuk mengatasi hambatan tersebut $\mathrm{Ibu} \quad \mathrm{SH}$ melakukan penilaian keterampilan sehingga untuk mengetahui apakah siswa paham atau tidak materi yang telah disampaikan.

Pembelajaran daring
dilaksanakan
menggunakan media
yang menyesuaikan
dengan kemampuan guru
dan kondisi siswa, untuk
aplikasi yang sering
digunakan adalah
whatsapp,aplikasi SSE,
serta google form.
Namun google
formhanya digunakan
saat ujian sekolah saja.
Namun
penggunaan aplikasi juga
masih terdapat kendala
karena adanya guru yang
kurang paham dengan
teknologi saat ini

Penggunaan media saat
pembelajaran daring seperti ini menggunakan aplikasi whatsapp. Di mana dalam aplikasi tersebut telah dibuat paguyuban kelas untuk guru dan siswa berinteraksi saat melaksanakan kegiatan belajar mengajar. Namun dalam penggunaan aplikasi whatsapp ini juga ditemukan berberapa hambatan seperti jaringan yang kurang stabil dan paket data habis.

\section{Sumber: Pengolahan Data}

Teknik penilaian praktik dilakukan oleh Ibu SH untuk mengetahui kemampuan siswanya dalam mempraktikkan teori pelajaran yang telah diberikan apakah sudah memahaminya atau belum, sehingga untuk penilaian pengetahuan juga dapat dilakukan dalam teknik penilaian keterampilan ini. Tugas praktik yang dilakukan yaitu pada pembelajaran SBDP yang di mana mempelajari cara bernyanyi yang baik dan benar, sehingga siswa diwajibkan untuk mempraktikkan cara bernyanyi yang sesuai dengan intonasi, irama, dan pelafalan lirik. Tugas keterampilan ini sesuai dengan muatan materi yang ada dalam Rencana Pelaksanaan Pembelajaran (RPP) tema 8 "Daerah Tempat Tinggalku," subtema 1 "Lingkungan Tempat Tinggalku," pembelajaran 2 ini juga sudah dilaksanakan. Dalam menilai hasil belajar praktik keterampilan menyanyi siswa ini yaitu, didapatkan melalui tugas yang diberikan di mana saat siswa mempraktikkan menyanyi lalu divideokan, cara penilaian ini sesuai dengan teori Wicaksana (2020) yaitu mengamati kegiatan praktik siswa. 
3193 Analisis Penilaian Keterampilan Kurikulum 2013 pada Pembelajaran Daring Kelas Tinggi Sekolah Dasar - Hani Subakti, Gamar Al Haddar, Elizabeth Angela Orin

DOI: https://doi.org/10.31004/basicedu.v5i5.1300

Menimbang karena sedang pembelajaran daring, jadi setiap hasil belajar siswa dikirim secara online dan dikirim melalui whatsapp pribadi Ibu SH menggunakan media gawai sebagai bukti bahwa siswa telah mengikuti proses belajar dan mengerjakan tugas yang diberikan. Dalam pelaksanaan teknik penilaian keterampilan praktik ini juga terdapat kendala yaitu di mana ada siswa yang kurang memahami tugas atau materi yang disampaikan, tetapi untuk mengatasi kendala tersebut Ibu SH akan memberikan penjelasan ulang dan meminta orang tua siswa membimbing anaknya saat proses belajar atau mengerjakan tugas keterampilan yang diberikan di rumah. Penilaian ini paling efektif dan mudah bagi Ibu SH untuk diterapkan selama proses pembelajaran daring karena saat melaksanakan kegiatan proses belajar keterampilan praktik siswa tidak terlalu mengalami kendala dan siswa juga dibimbing oleh orang tua saat proses belajar ataupun mengerjakan tugas di rumah.

Hasil penilaian keterampilan yang telah dilakukan Ibu SH menggunakan kriteria ketuntusan minimal 70 dengan menggunakan skala deskripsi nilai yang berupa huruf 1-100. Nilai hasil belajar siswa ini menunjukan bahwa nilai atau hasil yang didapatkan oleh siswa tidak ada yang di bawah kriteria ketuntasan minimal yaitu di bawah 70. Penilaian hasil keterampilan yang dilakukan melalui standar penilaian yang dilakukan oleh Ibu SH sendiri yang masih tetap berpacu pada kompetensi dasar penilaian.

Teknik penilaian produk siswa diberikan tugas membuat suatu karya, di mana hasil dari karya siswa akan dinilai. Karya yang pernah dibuat siswa adalah membuat montase, kolase, dan mozaik. Penilaian ini dilakukan untuk mengetahui bagaimana pemahaman siswa dan cara siswa mengaplikasikan pemahaman itu dengan membuat sebuah produk cara penilaian. Ini sesuai dengan teori Andriono (2019) yaitu penilaian terhadap keterampilan siswa dalam mengaplikasikan pengetahuannya. Saat memberikan tugas produk ini Ibu SH tidak hanya memberikannya pada muatan pelajaran SBDP saja melainkan pada muatan pelajaran lainnya juga tergantung pencapaian kompetensi dasar tujuan pembelajaran, sebelum memberikan tugas Ibu SH akan menjelaskan atau mempraktikkan terlebih dahulu cara membuat produk.

Penilaian keterampilan produk ini sesuai dengan muatan materi yang ada dalam rencana pelaksanaan pembelajaran (RPP) tema 3 "Peduli Terhadap Mahluk Hidup," subtema 1 "Hewan dan Tumbuhan di Lingkungan Rumahku," pembelajaran 2 ini juga sudah dilaksanakan dan mendapatkan hasil belajar dari siswa. Dalam teknik penilaian keterampilan produk ini siswa diminta membuat kolase yang dibimbing oleh orang tua di rumah, hasil dari karya kolase siswa dikirim melalui whatsapp pribadi Ibu SH dan akan dinilai sesuai dengan tujuan pembelajaran. Saat pelaksanaan penilaian keterampilan ini Ibu SH akan menyampaikan materi serta memberikan tugas kepada siswa dan untuk bukti bahwa siswa telah mengerjakan tugas keterampilan produk ini, siswa diwajibkan mengirimkan bukti karya berupa foto siswa bersama karya yang telah dikerjakan.

Teknik penilaian proyek dan portofolio tidak dilakukan karena menimbang saat pembelajaran daring seperti ini, akan sulit dilakukan karena memerlukan penjelasan dan bimbingan guru secara langsung. Penilaian proyek dan portofolio ini cendrung jarang dilaksanakan karena saat pembelajaran daring seperti ini Ibu SH memilih menggunakan teknik penilaian keterampilan yang bisa memudahkan siswa untuk memahami materi yang disampaikan. Teknik penilaian ini akan dilakukan jika diperlukan dan dalam rencana pelaksanaan pembelajaran (RPP) menerapkan menggunakan teknik penilaian.

Selama pembelajaran daring seperti ini penilaian hasil belajar siswa dinilai dari aspek penilaian keterampilan saja. Hal ini dikarenakan terkendala saat proses pembelajaran tidak dapat dibimbing secara langsung oleh guru. Sehingga untuk mengetahui apakah siswanya belajar atau tidak guru memberikan tugas di mana melibatkan siswa itu sendiri yaitu tugas keterampilan. Namun saat melaksanakan pembelajaran daring seperti ini juga terdapat hambatan yaitu dari susahnya guru dan siswa untuk beradapsi dengan proses belajar mengajar daring ini. Kemudian susahnya guru dalam menyampaikan penjelasan, tidak ada bimbingan secara langsung dari guru,dan siswa menjadi tidak paham akan materi yang disampaikan, serta jaringan internet yang jelek sampai tidak adanya paket data. 
3194 Analisis Penilaian Keterampilan Kurikulum 2013 pada Pembelajaran Daring Kelas Tinggi Sekolah Dasar - Hani Subakti, Gamar Al Haddar, Elizabeth Angela Orin

DOI: https://doi.org/10.31004/basicedu.v5i5.1300

\section{KESIMPULAN}

Berdasarkan hasil penelitian yang telah dilakukan maka peneliti menyimpulkan bahwa dalam penilaian keterampilan guru kelas IVB melakukan penilaian keterampilan dengan berberapa teknik yakni dengan teknik keterampilan praktik seperti yang sudah terlaksana. Dalam teknik keterampilan praktik di mana siswa diminta mempraktikkan cara bernyanyi yang sesuai dengan tujuan muatan materi yang akan dicapai, serta dalam penilaian keterampilan produk siswa diberikan tugas membuat kolase. Adapula teknik penilaian keterampilan yang tidak dilaksanakan yakni teknik penilaian keterampilan proyek dan portofolio karena sedang dalam pembelajaran daring, sehingga sulit untuk melakukan dua teknik penilaian ini. Setiap hasil tugas atau bukti belajar siswa dikirim ke whatsapp pribadi guru menggunakan media gawai yang berupa foto atau video. Jika didapati masih ada siswa yang belum memahami materi atau tugas yang diberikan maka guru kelas akan memberikan penjelasan ulang kepada siswa dan meminta orang tua siswa membimbing anaknya di rumah. Penilaian yang dilakukan juga menggunakan kriteria ketuntasan minimal (KKM) 70 dan dari hasil belajar 27 siswa mendapatkan nilai di atas kriteria ketuntasan minimal (KKM).

\section{DAFTAR PUSTAKA}

Agustian, Murniati, David Wijaya, And Ingridwati Kurnia. (2019). Keterampilan Dasar Dalam Proses Pembelajaran. Jakarta: Universitas Katolik Indonesia Atma Jaya.

Agustina, Nora.(2018). Perkembangan Peserta Didik. Yogyakarta: Budi Utama.

Andriono, Eko. (2019). Mudahnya Mengisi Nilai Dan Rapor Kurikulum 2013 Dengan "Si Nidra." Pontianak: Pgri Prov Kalbar.

Chomaidi, H., And Salamah. (2018). Strategi Pembelajaran Sekolah. Jakarta: Grasindo.

Creswell, John W. (2016). Research Design: Pendekatan Metode Kualitatif, Kuantitatif, Dan Campuran. Yogyakarta: Pustaka Pelajar.

Edi, Fandi Rosi Sarwo.(2016). Teori Wawancara Psikodignostik. Yogyakarta: Leutika Nouvalitera.

Gora, Radita. (2019). Riset Kualitatif Public Relations. Surabaya: Jakad Publishing.

Gusti, Sri, Nurmiati, Muliana, And Oris Krianto Sulaiman. (2020). Belajar Mandiri Pembelajaran Daring Di Tengah Pandemi Covid-19. Jakarta: Yayasan Kita Menulis.

Krismawati, Wiwik, Herdiwati, And Afiri N. Kurniawan. (2019). Instrumen Penilaian Keterampilan Mata Pelajaran Sosiologi Sma Lkpd (Lembar Kerja Peserta Didik). Yogyakarta: Uny Press.

Kuntarto, Eko, And Putri Susanti. (2016). "Persepsi Guru Terhadap Aspek Penilaian Sikap Dan Aspek Penilaian Keterampilan Dalam Kurikulum 2013 Di Sekolah Dasar.” 1(20):176-89.

Mamik. (2015). Metodologi Kualitatif. Taman Sidoarjo: Zifatama Publisher.

Moleong, And Lexy J. (2010). Metodologi Penelitian Kualitatif. Bandung: Remaja Rosdakarya.

Musfiqon. (2016). Penilaian Otentik Dalam Pembelajaran Kurikulum 2013. Sidoarjo: Nizamia Learning Center.

Nurhalimah, Sitti. (2019). Media Sosial Dan Masyarakat Pesisir. Yogyakarta: Budi Utama.

Paksi, Hendrik Pandu, And Lita Ariyanti. (2020). Sekolah Dalam Jaringan. Surabaya: Scopindo Media Pustaka.

Pohan, Albert Efendi. (2020). Konsep Pembelajaran Daring Berbasis Pendekatan Ilmiah. Jawa Tengah: Sarnu Untung.

Rusman. (2017). Belajar Dan Pembelajaran. Jakarta: Kencana. 
3195 Analisis Penilaian Keterampilan Kurikulum 2013 pada Pembelajaran Daring Kelas Tinggi Sekolah Dasar - Hani Subakti, Gamar Al Haddar, Elizabeth Angela Orin

DOI: https://doi.org/10.31004/basicedu.v5i5.1300

Sa'adah, Elvi Nur Lailatus, And Darsono Sigit. (2018). "Pengembangan Instrumen Penilaian Sikap Dan Keterampilan Psikomotorik Pada Materi Elektrokimia." Jurnal Pendidikan: Teori, Penelitian, Dan Pengembangan 3(8):1023-26.

Safitri, Dewi. (2019). Menjadi Guru Profesional. Riau: Indragiri Dot Com.

Sanjaya, Ridwan. (2020). 21 Refleksi Pembelajaran Daring Di Masa Darurat. Semarang: Universitas Katolik Soegijapranata.

Sarkadi. (2020). Tahapan Penilaian Pembelajaran Berdasarkan Kurikulum 2013. Surabaya: Jakad Media Publishing.

Setiawati, Wiwi. (2016). "Implementasi Penilaian Keterampilan Kewarganegaraan Berdasarkan Kurikulum 2013.” Jurnal Civicus 16(2):69-79.

Sudarsana, Ketut, Ni Gusti Ayu Made Yeni Lestari, And Komang Wisnu Budi Wijaya. (2020). Covid-19 Perspektif Pendidikan. Denpasar: Yayasan Kita Menulis.

Subakti, Hani. (2019). 8 Konsepsi Landasan Bahasa Indonesia Di Perguruan Tinggi. Parepare: Kaaffah Learning Center.

Subakti, H Danprasetya, K.H. (2021). Analisis Pembelajaran Daring Bahasa Indonesia Melalui Pemberian Tugas Pada Siswa Kelas Tinggi Sdn 024 Samarinda Utara. Jurnal Basataka (Jbt) 4(1) 46-53. Retrieved From Https://Jurnal.Pbsi.Uniba-Bpn.Ac.Id/Index.Php/Basataka/Article/View/109

Subakti, H. (2020). Hasil Belajar Muatan Bahasa Indonesiatema Peduli Terhadap Makhluk Hidup Menggunakan Reward Pada Kelas Iv Sdn 023 Samarinda Utara. Jurnal Basataka (Jbt), 3(1), 1-9 Https://Doi.Org/10.36277/Basataka.V3i1.80

Subakti, H. (2020). Hasil Belajar Muatan Bahasa Indonesia Tema Lingkungan Sahabat Menggunakan Media Spinning Whell Kelas V Sdn 007 Samarinda Ulu. Disastra: Jurnal Pendidikan Dan Sastra Indonesia, 2(2), 192-206. Doi:Http://Dx.Doi.Org/10.29300/Disastra.V2i2.3067

Sugiyono. (2016). Metode Penelitian : Kuantitatif, Kualitatif, Dan R\&D. Bandung: Alfabeta.

Wicaksana, Muhlis Fajar. (2020). Belajar Mengembangkan Model Penilaian Autentik Dalam Pembelajaran Bahasa Indonesia. Yogyakarta: Budi Utama.

Yuliani, Meda, Janner Simarmata, And Siti Saodah Susanti. (2020). Pembelajaran Daring Untuk Pendidikan Teori Dan Penerapan. Jakarta: Yayasan Kita Menulis. 